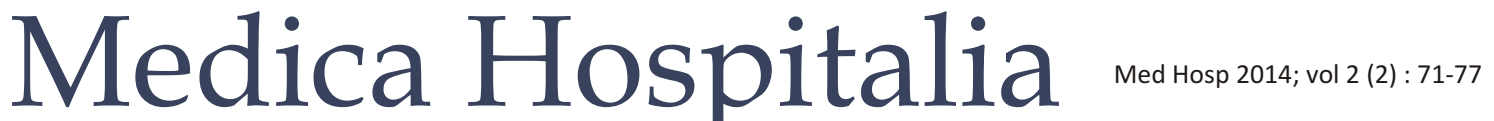

Review Article

Medical Progress

\section{Diphtheria di Jawa Timur}

\author{
Ismoedijanto*, Dwiyanti PP, Leni $\mathrm{K}^{*}$, Dominicus $\mathrm{H}^{*}$, Bambang $\mathrm{WK}^{* *}$ \\ *Divisi Infeksi dan Pediatri Tropik, Departemen Ilmu Kesehatan Anak RS Dr. Sutomo/FK Universitas Airlangga \\ **Dinas Kesehatan Provinsi Jawa Timur
}

\begin{abstract}
Abstrak
Imunisasi primer bermanfaat untuk membuat bayi kebal terhadap penyakit menular pada masa-masa permulaan kehidupan. Setelah cakupan imunisasi dasar telah mencapai $80 \%$, perlu imunisasi ulangan agar anak tetap terjaga kekebalannnya. Adanya Kejadian Luar Biasa (KLB) diphtheria di NIS (New Independent States, bekas negara bagian Rusia) dan juga di daerah padat pemukiman di Jawa, menunjukkan adanya masalah kekebalan pada anak dan dewasa. Kelompok anak tanpa kekebalan atau dengan kekebalan rendah terdiri dari kelompok yang sejak bayi tidak mendapat imunisasi sama sekali atau tidak lengkap dan kelompok yang kekebalannya menurun setelah beberapa waktu. Dengan cakupan imunisasi yang tinggi, kelompok ini lolos menjadi kelompok usia tua tanpa terpapar dengan kuman, tidak menderita penyakit diphtheri subklinis tetapi tetap rentan terhadap diphtheria. Kasus di Jawa Timur mulai muncul pada tahun 2005, dengan adanya KLB di Bangkalan. Dengan surveilans yang aktif intensif didapatkan adanya kenaikan jumlah kasus per tahun yang makin meningkat cepat dan pada tahun 2012 telah mencapai 956 kasus. Kenaikan kasus menunjukkan adanya "sesuatu" pada pelayanan kesehatan terutama program imunisasi kita. Selain suntikan primer untuk menimbulkan kelompok serokonversi, toksoid difteri dan tetanus perlu diulangi beberapa kali agar anak tetap kebal. Booster ini juga diharapkan akan menutup kekebalan kelompok anak yang tidak kebal akibat tertinggal pada putaran imunisasi primer. Sangat penting menjaga agar cakupan DTP tinggi dan merata, tanpa adanya kantong non kebal di setiap kabupaten.
\end{abstract}

Kata kunci : diphtheria, surveilans, gap kekebalan, kejadian luar biasa, booster.

\section{Diphtheria in East Java}

\section{Abstract}

Primary immunization benefits infant immunity toward early life infections. After $80 \%$ coverage $80 \%$ of the primary immunization, the booster immunization is recommended. The diphtheria epidemic which one accured in New Independent States (NIS) in ex Russia, and in one heavily populated area in Java, showed that there were an immunity problem in both children and adult. Those without the history of vaccination at all or not completely achieved vaccination or the ones with the declining immunity over some period of time are considered the vulnerable ones. At the location having high coverage immunization, the group would be survived from the disease, never exposure by the bacteria, but still to be vulnerable for diphtheria. Diphtheria epidemic occured in Bangkalan East Java at 2005. The active-intensive surveillance showed that the finding of the cases increased very fast and there was 956 cases in 2012. The increasing of cases showed that "something was wrong" at the health services especially of the immunization program. Besides the primary vaccination to achieve zero conversion group, diphtheria and tetanus toxoid are to be repeated to help the immune system of the children.

This booster is also expected to cover vulnerable/un-immuned children as a consequence of missing the primary vaccination. It is highly essential to keep the coverage of DTP high and evenly administered, not leaving anyone in every regency.

\section{PENDAHULUAN}

Penyakit diphtheria

Diphtheria adalah penyakit menular saluran nafas atas akut yang disebabkan oleh toksin kuman Corynebacterium diphtheriae. Toksin menyebar sistemik dan menyebabkan kerusakan pada epitel saluran nafas, jantung, saraf otak, saraf tepi dan ginjal. Kuman $\mathrm{C}$ diphtheria sendiri hanya berbiak dan berkolonisasi di saluran nafas atas, tidak menyebar, namun bila membran sangat tebal dapat menimbulkan sumbatan jalan nafas atas. Secara klinis di dapatkan membran abu-abu putih kotor pada farings, tonsil, trachea, laryngs, hidung, bahkan dapat pula pada lapisan epitel mata, vagina ataupun kulit. Difteri kulit pada tukak kronik merupakan salah satu sumber transmisi yang penting. Penularan terjadi lewat kontak langsung pribadi, baik secara kontak langsung dari kulit maupun dari droplet infection. 
Toksin difteri terdiri dari fragmen A dan B, fragmen $B$ mempunyai reseptor pada sel tertentu untuk memudahkan perlekatan dan memfasilitasi masuknya fragmen A yang toksik, sehingga protein yang terbentuk tidak terpakai dan menyebabkan kematian sel. Secara klinis toksin difteri menyebabkan kerusakan otot dan saraf dalam jantung, kelumpuhan pallatum molle, kelumpuhan otot mata dan muka, kelumpuhan saraf tepi (tangan) dan kerusakan ginjal. Penyakit ini terkenal di Eropa karena sumbatan saluran nafasnya menimbulkan berbagai cara untuk mengatasinya. Teknik tracheostomy menrupakan salah satu cara yg berkaitan dengan penyakit ini. Secara umum penyakit diphtheri tidak menarik perhatian orang awam, karena suhu badan subfebril dan hanya ada sedikit nyeri telan atau suara sengau. Sebagian besar orang tua penderita tidak mencari pertolongan medik yang memadai, hanya mengupayakan perawatan rumah tangga saja. Sebelum para orang tua mengerti dan sadar akan bahaya diphtheri, penyakit ini sudah menyurut akibat keberhasilan program imunisasi yang menyentuh akar rumput lewat PKK pada tahun-tahun yang silam.

\section{Kejadian difteri global}

Sebelum Kejadian Luar Biasa (KLB) besar di NIS (New Independent States $=$ negara pecahan Uni Soviet Rusia) tahun 90-an, data global menunjukkkan adanya penurunan kasus difteri global dengan akumulasi kejadian diphtheri terbanyak di South East Asia Region (SEARO).
Terjadi penurunan kasus secara global, dari sekitar 100.000 menjadi sekitar 7000 kasus (penurunan sekitar 93\%) dengan berhasilnya program EPI (Expanded Programme on Immunization) yang dilancarkan sejak tahun 1975. Setelah EPI berjalan sekitar 20 tahun, banyak region WHO telah berhasil melakukan imunisasi secara luas, teratur dan rapi, sehingga penurunan kasus menjadi konsisten misalnya region Amerika, Mediterranian Timur dan Pasifik Barat. Region Eropa (NIS) mengalami KLB besar pada tahun 1990-an, Afrika pada tahun 2000an. Region Asia Tenggara paling labil dengan angka yang fluktuatif, bahkan sampai tahun-tahun akhir ini kasus masih bermunculan. Cakupan dan kelengkapan jadwal imunisasi sangat berpengaruh, terutama untuk diphtheri yang memerlukan minimal 3 suntikan pada bayi untuk menjadikan kebal. Penyumbang penderita yang terbanyak adalah Asia Tenggara yang didominasi oleh India dan Indonesia, negara yang mempunyai populasi tanpa imunisasi yang cukup tinggi di dunia

\section{Kejadian Luar Biasa Penyakit Diphtheria di Jawa Timur}

Telah diramalkan sebelumnya

Diphtheria di Jawa Timur mulai menarik perhatian pada tahun 2005, saat terjadi KLB di kabupaten Bangkalan, Madura, dengan penyebaran yang jelas dan sumber penularan termasuk para petugas kesehatan (dokter) dan guru. Adanya KLB diphtheri pada saat itu dipakai sebagai petunjuk adanya kelemahan cakupan imunisasi

\section{TABELL 1}

\section{Penurunan kasus difteri global kecuali Asia Tenggara}

Regional and global summaries of diphtheria incidence (number of reported cases) : 1980, 1990, 1999-2008

\begin{tabular}{|c|c|c|c|c|c|c|c|c|c|c|c|c|}
\hline WHO regions & 1980 & 1990 & 1999 & 2000 & 2001 & 2002 & 2003 & 2004 & 2005 & 2006 & 2007 & 2008 \\
\hline African Region & 8.771 & 2.588 & 226 & 4.038 & 2.587 & 941 & 216 & 23 & 54 & 351 & 17 & 72 \\
\hline $\begin{array}{l}\text { Region of } \\
\text { the Americas }\end{array}$ & 5.570 & 826 & 122 & 113 & 68 & 128 & 99 & 181 & 272 & 285 & 103 & 102 \\
\hline $\begin{array}{l}\text { Eastern } \\
\text { Mediterranean } \\
\text { Region }\end{array}$ & 19.970 & 3.604 & 494 & 175 & 96 & 924 & 287 & 145 & 251 & 180 & 170 & 133 \\
\hline European Region & 618 & 3.202 & 1.614 & 1.585 & 1.386 & 1.189 & 897 & 688 & 500 & 320 & 228 & 184 \\
\hline $\begin{array}{l}\text { South-East Asia } \\
\text { Region }\end{array}$ & 47.354 & 11.582 & 2.170 & 5.470 & 6.045 & 5.583 & 4.596 & 8.874 & 10.908 & 3.016 & 3.675 & 6.502 \\
\hline $\begin{array}{l}\text { Western Pacific } \\
\text { Region }\end{array}$ & 15.228 & 2.062 & 184 & 244 & 543 & 257 & 736 & 158 & 759 & 75 & 80 & 95 \\
\hline Global & 97.511 & 23.864 & 4.810 & 11.625 & 10.725 & 9.022 & 6.831 & 10.069 & 12.744 & 4.227 & 4.273 & 7.088 \\
\hline No countries & 156 & 165 & 149 & 152 & 154 & 162 & 160 & 160 & 167 & 160 & 168 & 159 \\
\hline
\end{tabular}




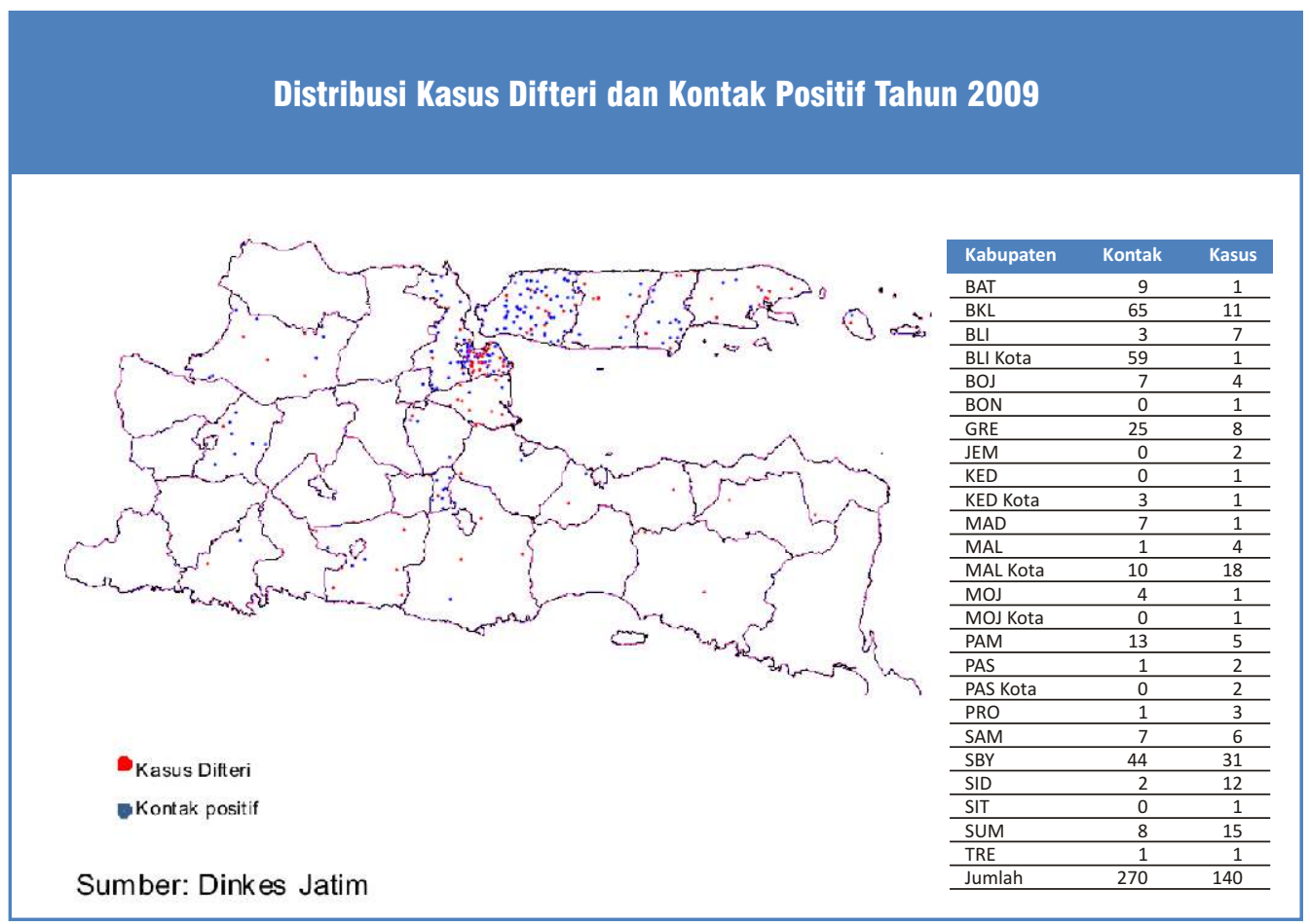

Gambar 1. Sebaran kasus dan KLB di urban /perkotaan

dan ternyata KLB polio liar dan disusul KLB VDPV dimulai dari daerah Bangkalan dan menyebar di pulau Madura. KLB diphtheri pada saat itu menimbulkan kekhawatiran akan merebaknya kasus diphtheri, mengingat vaksin toksoid diphtheri merupakan vaksin yang terlemah dalam vaksin kombinasi DTP. Dibutuhkan $3 \mathrm{x}$ suntikan dalam satu seri agar bayi menjadi kebal, dan terbentuknya herd immunity yang kuat. Evaluasi laporan kasus difteri nasional maupun laporan cakupan imunisasi DPT pada saat itu tidak menunjukkan adanya kecenderungan KLB di daerah penduduk padat (Sumatera, Jawa, Bali), kecuali adanya pergeseran kasus pada usia lebih tua. Dari data cakupan imunisasi polio dan KLB VDPV th 2005, telah difahami adanya kantong kantong tanpa imunisasi atau daerah dengan cakupan yang rendah, misalnya daerah pesisir utara Jawa Timur. Kekhawatiran rendahnya cakupan akan menimbulkan masalah makin dalam dengan adanya desentralisasi biaya operasional program imunisasi ke kabupaten/kota. Sejak surveilans AFP (untuk program Eradikasi Polio Global) juga diharuskan melakukan surveilans Penyakit yang Dapat Dicegah Dengan Imunisasi (PD3I), pencarian, pelaporan campak dan difteri digiatkan di Jawa Timur. Pengalaman adanya KLB diphtheri berulang di daerah Wlingi Blitar dan daerah Bangkalan memicu kegiatan surveilans diphtheri lebih serious. Sejak itu dilakukan pengamatan intensif pada semua kasus diphtheria dengan penyelidikan epidemiologik yang intensif, baik pada kasus indeks di RS ataupun kontaknya, sehingga terdapat kenaikan kasus. Adanya wabah import polio liar pada tahun
2005/2006 tidak mendorong peningkatan cakupan imunisasi rutin secara menyeluruh. Imunisasi tambahan vaksin polio berupa PIN/subPIN/mopping up tidak serta merta menaikkan cakupan imunisasi rutin, termasuk cakupan DTP.

Penyebaran kasus Pengamatan secara cermat dari data yang ada menunjukkan adanya kecendrungan kasus meningkat dari tahun ke tahun dan pada bulan Juli 2010 telah terekam 125 kasus di seluruh Jawa Timur. Kasus yang semula urban cases mulai berubah menjadi rural cases dengan timbulnya sebaran kasus ke kabupaten selatan Jawa timur, misalnya Tulung Agung dan Lumajang

Kenaikan kejadian KLB dan kasus makin melaju, jumlah kabupaten/kota yang melaporkan makin banyak. Meskipun sejak tahun 2008 telah didiskusikan masalah ini, namun belum ada intervensi yang intensif (imunisasi tambahan) untuk menekan kasus secara keseluruhan. Intervensi terbatas pada perawatan penderita, pemeriksaan kontak, pemberian eritromisin pada kontak yang positif untuk mencegah penularan lebih lanjut. Imunisasi rutin dicoba ditingkatkan.

Pada permulaan KLB, terjadi beberapa kendala logistik, misalnya tidak adanya ADS atau penicillin procain di kabupaten karena menurunnya kasus pada tahun-tahun sebelumnya. Isolasi penderita kurang difahami masyarakat sehingga banyak kasus pulang paksa dari rumah sakit atau dirawat di Puskesmas perawatan dengan fasilitas minimal. Standar perawatan termasuk isolasi dan penekanan jumlah sumber penularan kurang berhasil sehingga kasus makin 


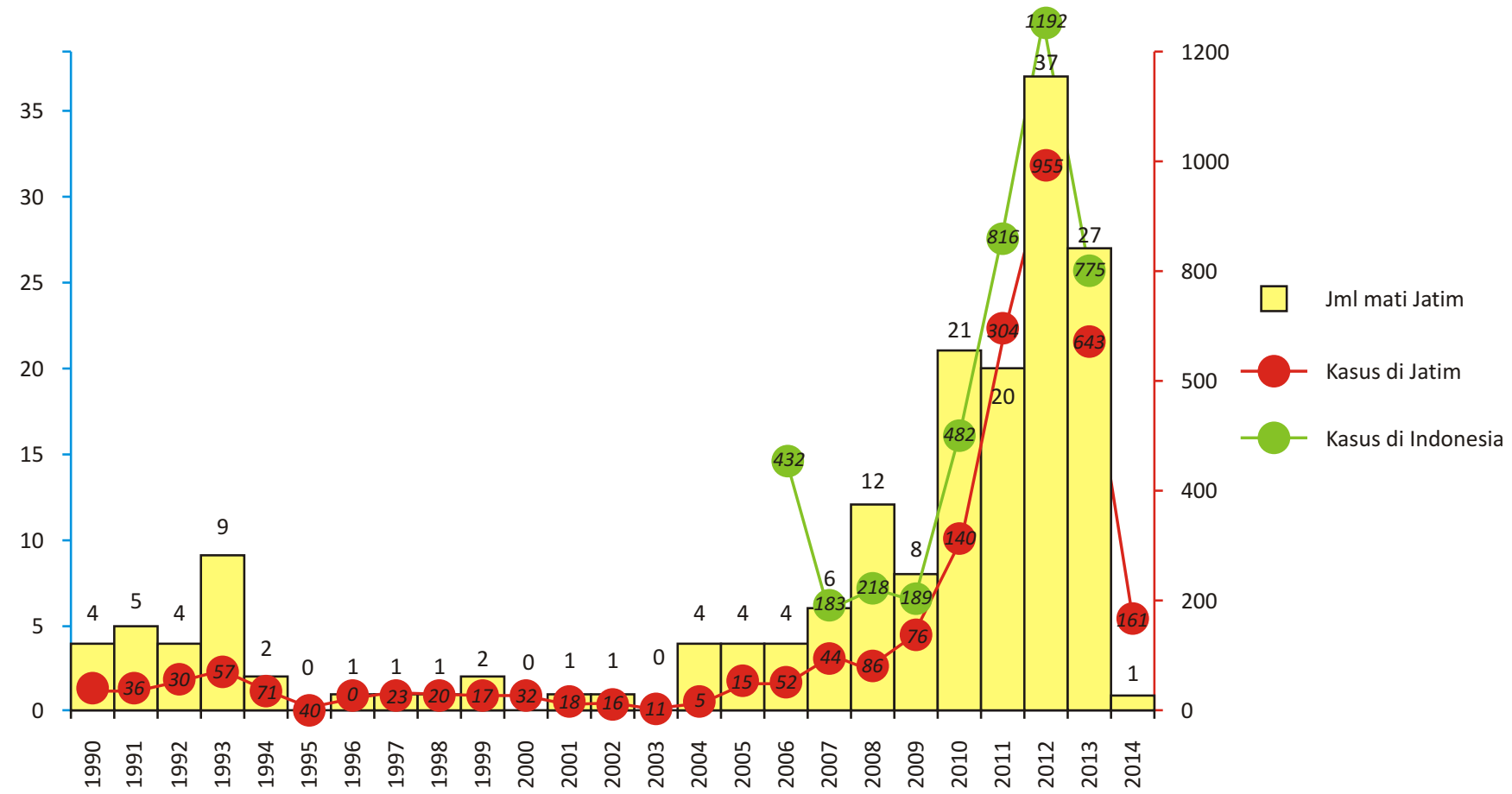

Gambar 2. Distribusi kasus diphtheri pada kabupaten/kota yang melaporkan

melebar. Studi penularan di Blitar menunjukkan penularan dan sirkulasi kuman diphtheri yang intensif dan berkelanjutan terjadi di antara anak dan dewasa pada komunitas terbatas (dinas kesehatan kabupaten).

Diphtheria adalah penyakit yang menular, bahkan jelas aturan tatalaksananya pada UU Wabah Indonesia. Penampilan klinik diphtheri yang "kalem" (kecuali pada kasus diphtheri laryng yang memerlukan tracheostomy), menyebabkan penderita kurang cepat mencari pengobatan dan datang ke rumah sakit sudah dalam keadaan lanjut (gagal jantung), terlihat pada pendeknya jarak waktu antara masuk rumah sakit dan saat kematian penderita. Kasus penyakit ini juga pernah menurun sekali, sehingga banyak dokter, rumah sakit ataupun perawat yang kurang faham dan pengalaman menangani baik pengobatan maupun pencegahan penularan penyakit ini pada masyarakat.

Konsentrasi kasus masih tetap pada daerah pemukiman padat, seperti Surabaya, Bangkalan, Sampang, Sidoarjo karena semakin padat, semakin tak terjangkau, semakin cepat penjalaran kasus. Sebuah ledakan besar terjadi di Situbondo, kabupaten yang hampir terlupakan, proporsi kasus mulai mengarah pada anak besar dan dewasa. Imunisasi tambahan pada semua usia di suatu kecamatan yang berhasil menghentikan transmisi penularan membuktikan adanya gap kekebalan pada populasi daerah ini.

\section{Apakah memang ada KLB?}

Balai Besar Laboratorium Kesehatan di Surabaya telah berubah dari laboratorium epidemiologik menjadi laboratorium umum di bawah direktorat pelayanan medik, meskipun masih berfungsi sebagai laboratorium rujukan polio global. Tugas yang berubah menyebabkan penurunan kemampuan mengisolasi, sampai memeriksa toksigenisitas kuman diphtheri. Adanya kasus dan biakan kuman yang positif tanpa tes toksigenisitas tidak menyakinkan adanya KLB di Jawa Timur. Diupayakan bantuan dari laboratorium rujukan diphtheri global dari Eropa (yang berpengalaman mengatasi KLB di Rusia pada tahun 1990-an) yang akhirnya mampu mengembalikan kompetensi laboratorium memenuhi syarat epidemiologik internasional yaitu melakukan biakan hapusan tenggorok dan tes toksigenisitas serta ribotyping. Pemeriksaan BBLK Surabaya sejak tahun 2011 diakui ketepatannya dan dengan data ini diupayakan validasi dan tindak lanjut penangan KLB. KLB mulai menggunakan kriteria WHO region Eropa yaitu biakan kuman positif yang toksigenik, mengingat banyaknya kuman diphtheri yang bersifat komensal pada manusia dan binatang.

\section{Mengapa terjadi KLB?}

\section{Imunisasi dan kasus diphtheria}

Pada saat bayi lahir, di dalam tubuhnya masih mengalir antibodi anti difteri yang diberikan oleh ibunya pada saat trimester kedua kehamilan dan pada saat paparan kuman yang tinggi pada masa bayi (masa pra vaksin), antibodi maternal menjaga agar bayi tidak sakit, sekaligus paparan tersebut memicu kekebalan alamiah secara bertahap, sehingga anak tetap kebal. Penelitian 


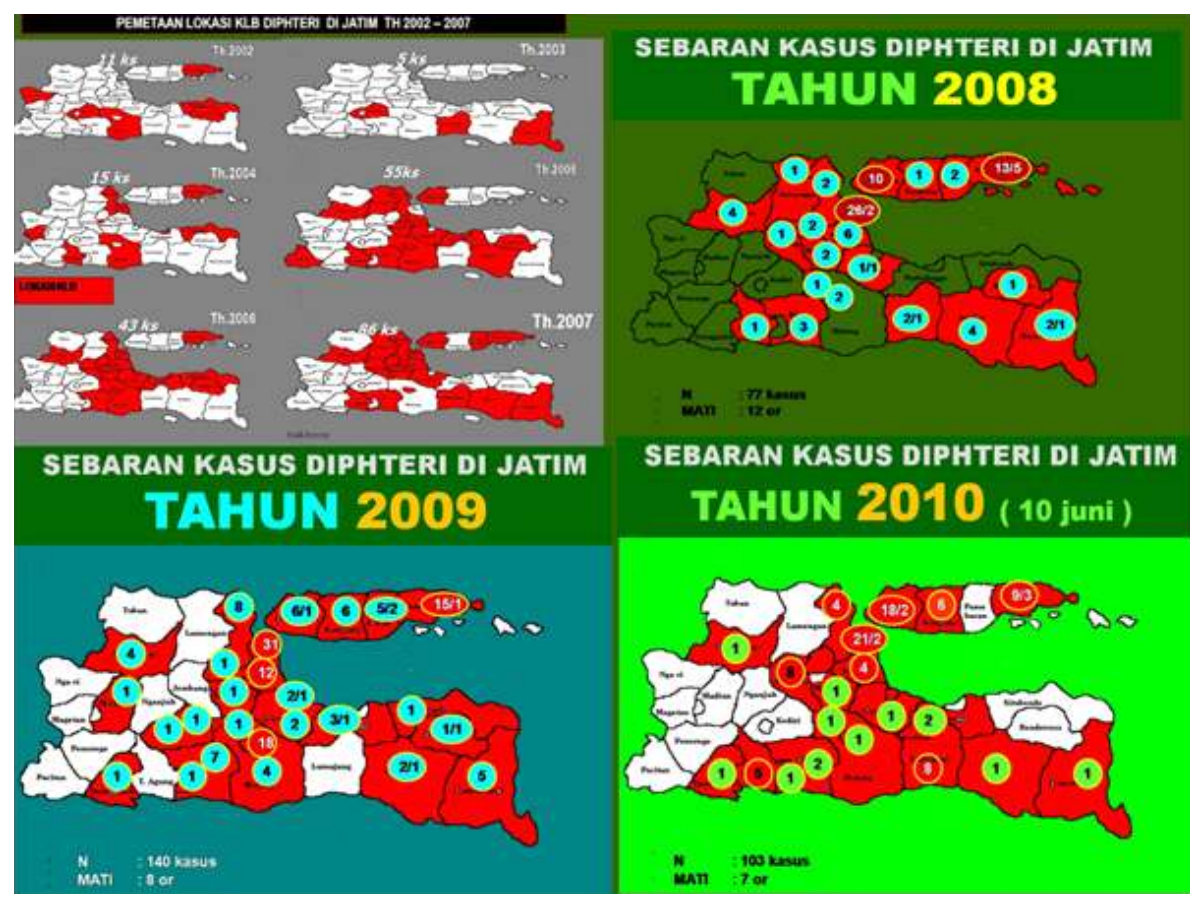

Gambar 3. Perluasan daerah KLB di Jawa Timur : cluster di perkotaan dan hunian padat penduduk di tapal kuda Jawa Timur dan daerah-daerah sentra ekonomi

Parwati dkk menjelaskan bahwa bilamana suntikan vaksin difteri diberikan pada usia yang muda (2 bulan) dimana antibodi maternal masih tinggi, maka diperlukan 3 suntikan lengkap agar antibodi anti difteri naik tinggi dan protektif. Setelah imunisasi primer DTP rutin diterapkan pada masa bayi, kekebalan ibu yang didapat secara alamiah diganti dengan kekebalan akibat vaksin dan selanjutnya dijaga titernya dengan suntikan ulangan/booster. Pada saat bersamaan, sirkulasi kuman difteri yang toksigenik menurun, sehingga paparan makin kurang dan perannya memberi booster alamiah makin menurun. Akibatnya adalah bilamana anak tidak mendapat imunisasi dasar atau imunisasi dasarnya tidak lengkap, peranan booster alamiah kuman difteri yang beredar berkurang dan anak menjadi rentan. Cakupan imunisasi primer DTP di atas $70 \%$ akan memulai terbentuknya herd immunity yang akan menurunkan penyebaran kuman dan bilamana cakupan meningkat, kasus akan menghilang.

\section{Pentingnya booster dan cakupan imunisasi primer merata}

Tokoid difteri tidak sekuat toksoid tetanus, vaksin yang paling imunogenik. Masalah pertama adalah imunisasi dasar harus terdiri dari beberapa suntikan untuk menghasilkan kadar di atas kadar protektif sehingga bayi yang tidak kebal menjadi kebal.

Imunisasi dengan toksoid difteri harus dilakukan minimal 3 kali, bertahan kadarnya sekitar setahun, sehingga harus diberikan booster untuk meningkatkan kembali kadar antibodinya di atas kadar proteksi.
Imunogenisitas toksoid diphtheri sudah diperkuat dengan pemakaian adjuvant garam aluminium dan peran antigen pertussis whole cell sebagai biological adjuvant. Sejak PPI (Program Pengembangan Imunisasi di Indoneia sebagai adaptasi EPI - Expanded Programme on Immunization Global) telah dikemukakan perlunya menyertakan booster pada usia 2 tahun dalam jadwal imunisasi nasional. Penelitian Kusnandi Rusmil dkk pada saat KLB di Cianjur menekankan perlunya booster pada usia 2 tahun, agar tidak terjadi gap kekebalan sebelum BIAS. Namun dengan alasan keterbatasan dana dan kesulitan mengumpulkan anak usia di atas setahun di meeting points imunisasi, booster tersebut tidak diberikan. Baru pada PERMENKES 42 tahun 2013, booster pada usia 2 tahun masuk kedalam program imunisasi rutin anak di Indonesia. Beberapa negara lain telah menetapkan, bahwa imunisai primer adalah 3 suntikan sebelum satu tahun dan booster sesudahnya. Cara ini terbukti dapat menutup jendela tidak kebal atau gap kekebalan, sebelum anak mendapat suntikan booster pada usia masuk sekolah, sekitar 6-7 tahun. Booster selanjutnya diberikan setiap 10 tahun.

Masalah kedua adalah masalah cakupan imunisasi. Program imunisasi dengan meeting points Posyandu dan Puskesmas telah terbukti menurunkan insidens kasus PD3I. Melemahnya kegiatan pelayanan kesehatan mandiri di Posyandu dan hilangnya juru imunisasi mungkin memicu timbulnya kantong-kantong non imunisasi di lingkar luar pelayanan PKM. Tenaga kesehatan pengganti juru imunisasi mempunyai tugas lain yang lebih berat (bidan dan perawat), sehingga 


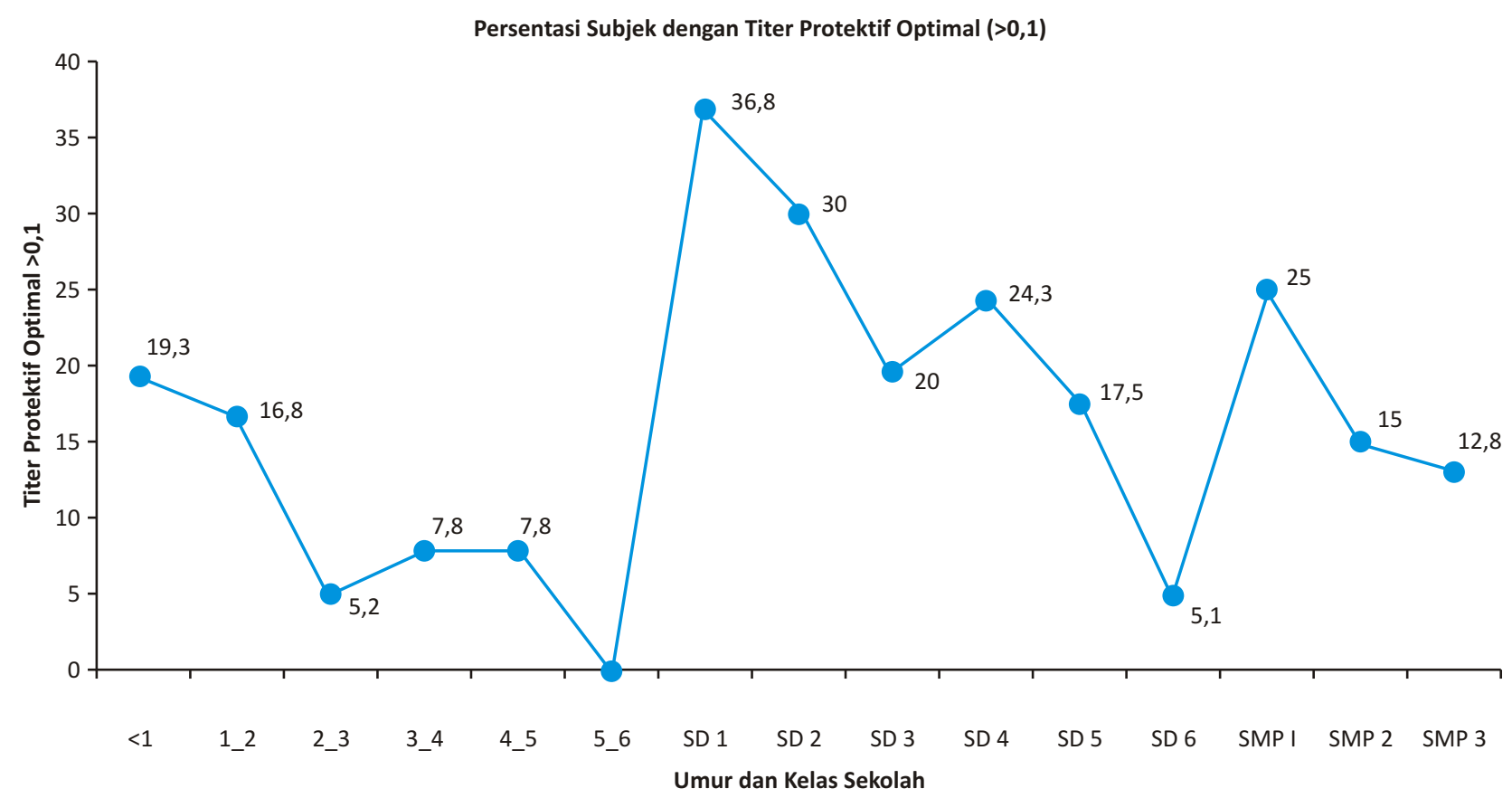

Gambar 4. Proporsi kekebalan anak kelompok usia pada saat KLB Cianjur (dikutip dari Kusnandi R dkk)

Kasus diphteri dan imunisasi DPT3 - DT-SD di Jawa Timur (s/d 10 Juni 2010)

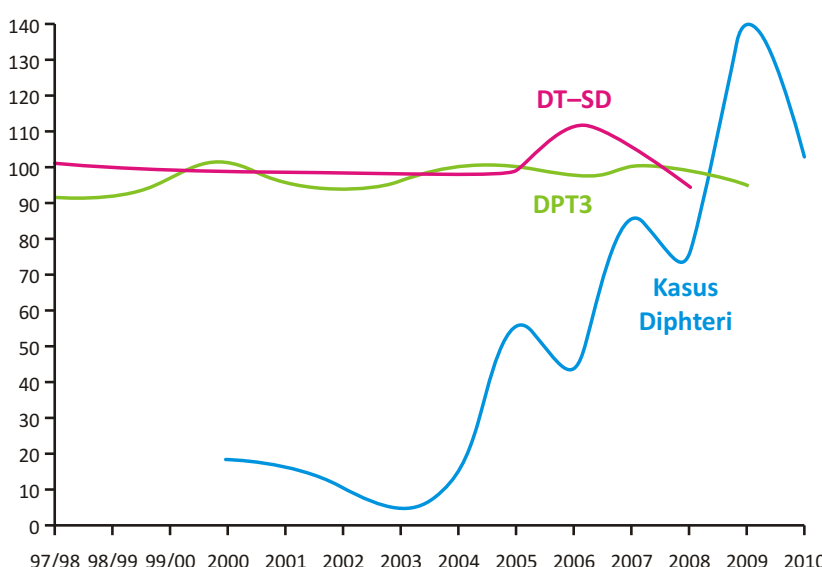

Gambar 5. Kasus meningkat dengan cakupan imunisasi dasar dan BIAS yang tinggi.

hanya cakupan di sekitar PKM yang tinggi dan bila rerata dilakukan pada tingkat PKM atau Kabupaten maka cakupan akan berada diatas angka cakupan minimal. Tanpa sweeping dan backlog fighting, akan tersisa kantong kantong di pinggiran daerah cakupan pelayanan PKM yang makin lama akan makin tua usianya dan akan berbaur ke luar daerah kantong karena sekolah dan kerja dan tetap rentan. Data surveilans AFP kasus VDPV, ternyata sebagian besar kasus dan anak anak sekitar kasus tidak pernah mendapat imunisasi polio, meskipun anak sudah sekolah di SD. Adanya kantong kantong non imunisasi, dan diperbolehkan UCI provinsi atau kabupaten (bukan UCI desa seperti disepakati semula), menjelaskan mengapa laporan cakupan imunisasi tidak berkaitan dengan kenaikan kasus difteri di suatu daerah.

\section{Lesson learned}

\section{Surveilans dan imunisasi}

Tidak akan ada kasus diphtheri bilamana tidak dilakukan surveilans secara cermat. Peran surveilans secara ketat pada kasus PD3I sangat penting untuk menjaga kualitas dan kuantitas program imunisasi. Perangkat evaluasi yang dimiliki program imunisasi adalah perangkat tidak langsung yang dijalankan program itu sendiri, laporan cakupan juga sangat tergantung pada ketepatan cohort (banyaknya bayi lahir) sebagai denominator dan kemampuan melakukan mikroplanning. Adanya kasus PD3I yang ditemukan dan diselidiki oleh surveilans merupakan ukaran yang lebih nyata apakah imunisasi dan cakupannya telah mampu membentuk herd immunity di suatu daerah atau tidak.

Program imunisasi telah terbukti mampu membentuk herd immunity yang kuat terhadap diphtheri pada masa lalu, melihat data kasus yang rendah. Bilamana surveilans menemukan kenaikan kasus, secara bijak kita harus melakukan evaluasi dan memperbaiki kelemahan yang ada, bukan menyembunyikan seolah bukan suatu masalah. 


\section{DAFTAR PUSTAKA}

1. Alan RT, Sri Rezeki SH, Ismoedijanto. Difteria, Tetanus dan Pertusis. Dalam: Pedoman imunisasi di Indonesia eds IGN Gde Ranuh 2011:285-288

2. Dep Kesehatan RI. Laporan tahunan cakupan imunisasi tahun 2002-2006. subdit Imunisasi, Direktorat Sepim Kesma, Ditjen PP-PL. 2007

3. Dep Kesehatan. Laporan kasus PD3I, subdit Surveilans tahun 2000-2007, Direktorat Sepim Kesma, Ditjen PP-PL. 2008

4. Departemen Pendidikan. Rangkuman Nasional Statistik Sekolah Dasar (SD-MI) tahun 2006, Direktorat Pembinaan Taman Kanak-kanak dan Sekolah Dasar, Dirjen Manajemen Pendidikan Dasar dan Menengah Departemen Pendidikan Nasional, tahun 2006. 2006:1.

5. Dinas Kesehatan Propinsi JawaTimur. Prosedur tetap penanggulangan KLB Diphtheria di Jawa Timur. 2010

6. Dittman Sieghart, Melinda Wharton, Charles Vitek, Arthur Galazka et al. Successful control of Epidemic Diphtheria in the states of the former union of the Soviet Socialist republics: lesson learned. JID 2000;181 (S1):S10

7. Galazka A. The changing epidemiology of diphtheria in the vaccine era. JID 2000;181(S1):S2

8. Ismoedijanto dan Dominicus Husada. Dalam : Prosiding Simposium Imunisasi IDAI ke 3. Eds Partini PT, Hanifah O, Hartono G, Aryanto H 2012:12-31

9. Plotkin SA. Vaccines, vaccination, and vaccinology. JID 2003.;187:1349
10. Rusmil Kusnandy, Alex Chairulfatah, Eddy Fadlyana, Meita Dhamayanti. Wabah difteri di kecamatan Cikalong Wetan, Kab Cianjur barat, Jawa Barat, Indonesia. 2001:12(6);397-403

11. Sri Rezeki SH. The value of immunization. Dalam : Pedoman imunisasi di Indonesia eds IGN Gde Ranuh 2011:11-35

12. Tharmaphornpilas $P$, Yoocharoan $P$, Vitek CR. Diphtheria in Thailand in 1990s.JID 2001;184:1035

13. Usmanov Ismatulo, Michael O Favorov. Universal immunization: The Diphtheria control strategy of choice in the Republic of Tajikistan, 1993-1997. JID 2000; 181:(S1), S86

14. Vitek CR, Wharton M. Diphtheria toxoid dalam Vaccines eds Plotkin SA, Orenstein WA, Offit PA 2008, hal 139-156.

15. Vitek CR, Wharton M. Diphtheria in the former Soviet Union:reemergence of a pandemic disease. Emerg infect dis $1998 ; 4: 539$

16. WHO, 1994. Diphtheria, Manual for the management and control of Diphtheria in the European Region. ICP/EPI 038

17. WHO. Module 2: Diphtheria update 2009, WHO 2009

18. WHO. Weekly epidemiological record, No. 3, 2006, 81. 20 January 2006, page 24--32.

19. WHO. Weekly epidemiological record, No. 37, 11 September 1998, page 283-284.

20. Yulia Iriani, Catalina Fetri Katanuba, Dian Puspita sari, Mutiara Budi Azhar, Wisman Tjuanda, Zarkasi Anwar. Kadar imuniglobulin $\mathrm{G}$ difteri dan tetanus pada anak sekolah dasar kelas satu Sari Pediatri 2012: 12(1);46-51 